TITLE:

\title{
MARINE INSECTS OF THE TOKARA ISLANDS -VII. NEW SPECIES AND NEW SUBSPECIES OF THE SUBFAMILY TRECHINAE (COLEOPTERA, HARPALIDAE)-
}

\author{
$\operatorname{AUTHOR}(\mathrm{S})$ : \\ Ueno, Shun-ichi
}

CITATION:

Ueno, Shun-ichi. MARINE INSECTS OF THE TOKARA ISLANDS -VII. NEW SPECIES AND NEW SUBSPECIES OF THE SUBFAMILY TRECHINAE (COLEOPTERA, HARPALIDAE)-.

PUBLICATIONS OF THE SETO MARINE BIOLOGICAL LABORATORY 1955, 4(2-3): 403-413

ISSUE DATE:

1955-05-30

URL:

http://hdl.handle.net/2433/174509

RIGHT: 


\title{
MARINE INSECTS OF THE TOKARA ISLANDS \\ VII. NEW SPECIES AND NEW SUBSPECIES OF THE SUBFAMILY TRECHINAE (COLEOPTERA, HARPALIDAE) $)^{1}$
}

\author{
SHUN-ICHI UÉNO \\ Zoological Institute, College of Science, Kyoto University
}

With 7 Text-figures

The carabid-fauna of the Tokaras, a group of small islands which lie between the Islands of Yakushima and Amami-Ôshima, south-west of Kyushu, should be looked for with great interest from the zoögeographical point of view. It is remarkably different from that of any other part of Japan, even from that of the Island of Yakushima that is situated in a distance not exceeding $170 \mathrm{~km}$ north-east from Takarajima, southernmost one of the islands concerned. Moreover, there is a distinct difference between the carabid-faunae even within the Tokaras, that of the southern and that of the northern. In Nakanoshima, one of the northern islands, the Palaearctic elements seem to be dominant to a certain degree, while in Takarajima, one of the southern, the inhabitants are of quite Oriental. Many tropical species spread over Formosa to Takarajima, but do not extend to Nakanoshima. When the examples are taken up from the subfamily Trechinae, the northern limits of Lymnastis pilosus H. W. BAtes, Polyderis impressipennis (MOTSchulsky) and Eotachys euryodes (H. W. BATES) are, so far as has been known to the writer, found in the Island of Takarajima. This is an important fact which resembles the distribution of several reptiles, such as Typhlops braminus (DAUDIN), Liopeltis semicarinata fritzei MAKI and Trimeresurus flavoviridis tokarensis NAGAI.

On the western coast of the Island of Nakanoshima, there have been found two marine species of Caraboidea, both belonging to the tribe Bembidini of the subfamily Trechinae. They seem to be new to science. In this paper are described these marine forms together with conveniently two other new forms of the subfamily. The writer should describe here one more new species, Eotachys troglophilus S. UÉNo (in litt.). However, the recent discoveries of this species in Kyushu and Shikoku has compelled him to revise the species, and the publication of its description will be adjourned until the species will be re-examined. The type-specimens of the new

1) Scientific Survey of the Tokara Islands, Report No. 21.

Publ. Seto Mar. Biol. Lab., IV (2-3), 1955. (Article 35) 
species and new subspecies described in this report are deposited in the collection of the present writer and of the Osaka Municipal Museum of Natural History.

The writer wishes to express his cordial thanks to Mr. Yoshitaka Tsursur, the director of the Osaka Municipal Museum of Natural History, who kindly gave the writer the opportunity to join the Tokara Expedition 1953 under his leadership. The study of the collection made during the Expedition was carried on in the Entomological Laboratory of Kyoto University under the supervision of Prof. Syunro UTIDA and was continuously encouraged by Prof. Takasi TokiokA, of the Seto Marine Biological Laboratory, one of the members of the Expedition. To these professors the writer's hearty thanks are due. Best gratitudes should also be expressed to Messrs. Akinobu HaBu of the National Institute of Agricultural Sciences and Kazuyoshi Kurosa of Saéki City for their kind assistance in supplying useful material for comparison.

\section{Trechoblemus microphthalmus S. UÉNo, sp. nov.}

Trechoblemus microphthalmus S. UÉno, 1953 (in litt.), Shin Konchû, Tokyo, 6 (11) : 43.

Length : $3.35-3.55 \mathrm{~mm}$ (from front margin of clypeus to anal end).

Brachypterous. Body elongate and depressed; pubescent; all the setae so remarkably long as those in the cavernicolous species. Pale reddish brown to reddish brown, head rather darker; dull-shiny, elytra somewhat opalescent; as the elytra are translucent, a vague longitudinal dark marking is seen through each of them according to individuals; appendages paler.

Head large, with distinct frontal furrows; eyes small, hardly prominent; genae remarkable, longer than eyes and convex; neck wide; surface sparsely pubescent, microsculpture consisted of well marked reticulation; antennae stout, subfiliform, reaching basal two-fifths of elytra, with apical segments a little oval.

Pronotum transverse-subcordate, moderately convex, about 1.25 times wider than head, wider than long in a same proportion, widest at about apical one-fourth; base truncated, slightly narrower than apex which is slightly but widely emerginate; sides gently rounded in front, weakly sinuate before hind angles which are rectangular and each with a postangular seta, front angles rounded; median line deep; front transverse impression shallow but evident; basal transverse impression deep, with a longitudinal narrow pore on each side of median line, and merging on each side into a large and deep basal fovea; surface finely and rather closely punctate, mesh-like microsculpture present though indistinct.

Elytra elongate with nearly parallel sides, moderately convex but flat on disk, fully 1.3 times wider than pronotum, about 1.8 times longer than wide (the ratio somewhat variable according to individuals); shoulders distinct; punctate-striate, striae shallow especially on both sides though clear, striae 1 and 2 becoming deeper towards apex, scutellar striole present, apical striole deep; intervals slightly convex near suture, flat on the sides, with irregular rows of punctures; stria 3 with two dorsal 
pores placed at about basal one-fifth and a little behind middle respectively, preapical pore close to apex and adjoining stria 2; microsculpture consisted of transverse lines but indistinct.

Legs stout; protibiae not externally grooved.

Male gential organ small and moderately chitinized. Aedeagus elongate, moderately arcuate, so swollen out before apex that the ventral side is evidently convex; apex somewhat prolonged into a blunt point; sagittal aileron well developed. Inner sac armed with a large spatulate copulatory piece which is covered with numerous scales and is symmetrically placed in the sac with the guttered face ventrally, apical part of this piece membraneous. Styles wide, left style a little longer than right, each provided with four setae at apex.

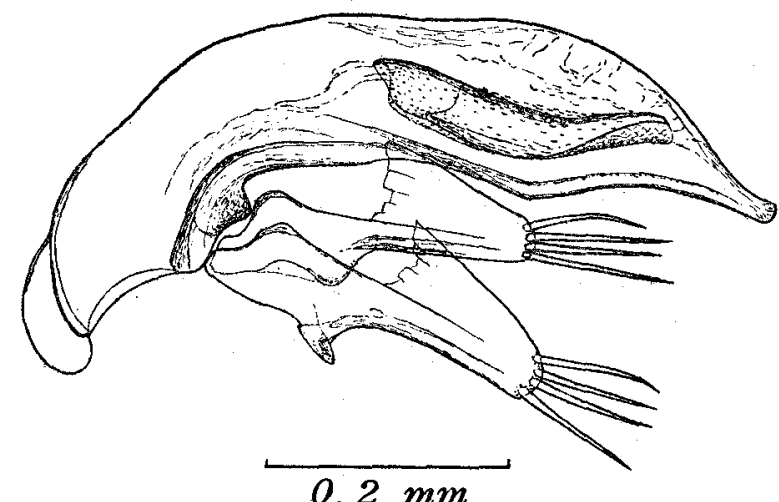

Fig. 1. Male genital organ of Trechoblemus microphthalmus S. UÉNO, sp. nov.; left lateral view.

Holotype: 3 , allotype: 우, paratypes: 1$\}, 2$ 우우 $(29,30-\mathrm{V}-1953$, collected by S. UÊNO).

Type-locality: Ôiké, on the island of Takarajima, one of the Tokara Islands.

The present new species is a close relative of the European T.micros (HERBST), but is easily distinguished from the latter by its smaller size of body, the smaller eyes, and the quite different structure of the male genital organ.

Ôiké is a small marsh situated in a hollowed depression between the dune and the scrubby hill on the small island of Takarajima. After heavy rain, however, the marsh becomes full-filled with water forming a lake suddenly. On May 27th and 28th, 1953, the island was attacked by a typhoon and the downpour caused flood in Ôike. All the inhabitants of the marsh were so driven out from their shelters that let the writer to be able to obtain so many interesting carabids as to include many genera and species which were all newly added to the Japanese fauna. The present new species was also found at that opportunity. 
Armatocillenus (Corallicillenus subgen. nov.) tsutsuii S. UÉNo, sp. nov.

Length: $3.3-3.9 \mathrm{~mm}$ (from front margin of clypeus to anal end).

Body elongate; surface impunctate and glabrous; metathoracic membraneous wings rudimentary. Reddish brown, depigmented and dull-shiny; palpi, antennal segments $1-3$ and legs light reddish brown.

Head large and wide, with frontal furrows which are deep, wide, parallel and extending onto clypeus; eyes rather small, a little prominent and coarsely faceted, much longer than genae which are slightly convex; supraorbital carinae obtuse though prominent; neck very wide; labrum very transverse; microsculpture consisted of isodiametric meshes which are rather slight on front and vertex; mandibles elongate, hooked at apices; antennae stout, extending a little beyond basal one-fourth of elytra, segments 8-10 distinctly ovate, forming the submoniliform apical part.

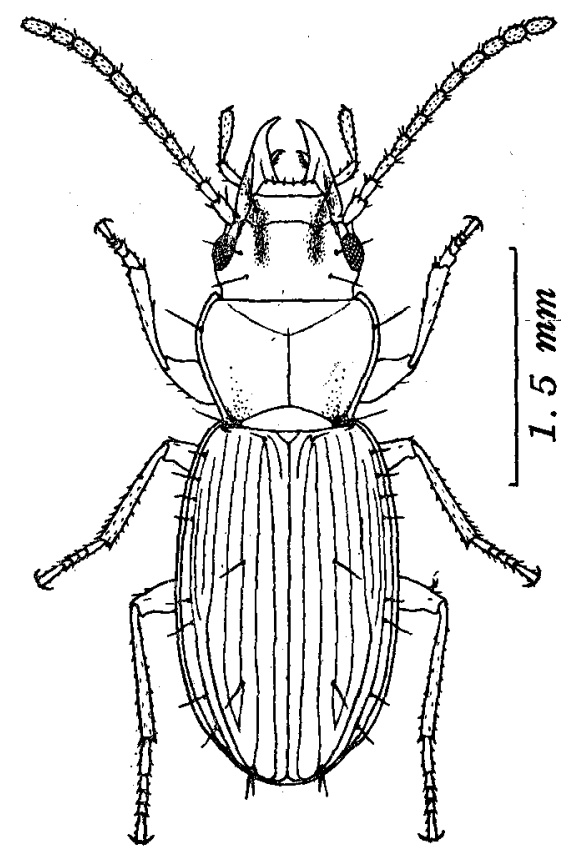

Fig. 2. Armatocillenus tsutsuii S. UÉNO, sp. nov., ô.

Pronotum transverse sub-cordate, contracted behind, moderately convex; about 1.2 times' wider than head, $1.30-1.35$ times wider than long according to individuals, widest at about three-fourths from base; sides sharply reflexed throughout, gently rounded in front and very slightly sinuate behind; side-gutter evenly deep along the whole length of side-border, with one lateral seta at apical one-fifth or more in front according to individuals; apex slightly but widely emarginate; base distinctly narrower than apex, about seven-eighths as wide as the latter, produced at the median part 
and emarginate on each side just inside hind angles, which are consequently projected backwards and sharp; front angles well projected forwards and a little blunt at the tip; median line distinct, extending beyond neither front transverse impression nor basal sulcus; front transverse impression slight, with several vague punctures; basal transverse sulcus continuous, arcuate, evenly deep and merging on each side into basal fovea which is small but deep; surface somewhat depressed longitudinally on each side in front of basal sulcus and inside side-gutter, forming posteriorly a very obtuse ridge between this depression and side-gutter; microsculpture formed by isodiametric meshes but rather faint on disk.

Elytra elongate, moderately convex, fully 1.2 times wider than pronotum, about 1.65 times longer than wide (the ratio somewhat variable according to individuals); shoulders effaced; sides slightly rounded at middle and slightly emarginate before

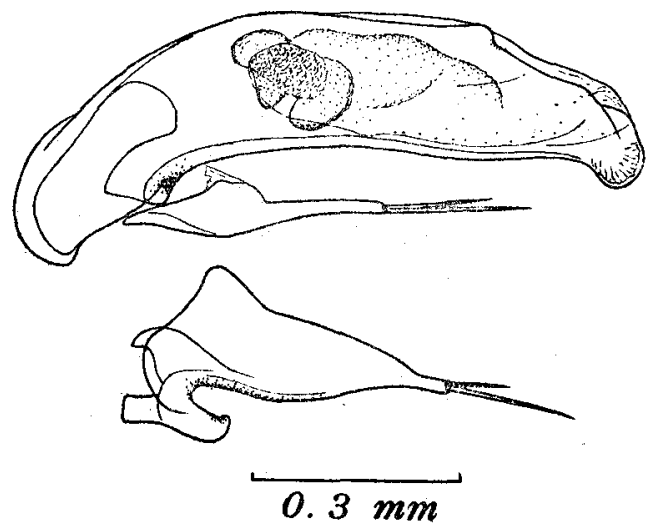

Fig. 3. Male genital organ of Armatocillenus tsutsuii S. UÉNO, sp. nov.; left lateral view, with left style removed.

apices; striae deep, impunctate, stria 5 deepening behind middle and merging into apical striole; intervals a little convex, interval 5 widening out behind middle and forming outside a remarkable apical carina; interval 3 with two dorsal pores nearly adjoining stria 3 , placed at about two-fifths and three-fourths from base respectively; nearly isodiametric microsculpture well developed throughout.

Legs short and stout.

Male genital organ similar in structure to that of Armatocillenus aestuarii. Aedeagus relatively a little more elongate and more arcuate, with apex much strongly bent; ventral side a little convex before apex. Right style comparatively long and with long apical prolongation; each style furnished with two apical setae as in $A$. aestuarii.

Holotype: $\hat{o}$ (Amadomari, 6-VI-1953, collected by S. UÉNo); allotype: 우 (Yoriki, 4-VI-1953, by S. UÉNO). 
Paratypes: 14 ㅅํㅇㅅ, 10 우우 (Yoriki, 4VI-1953, by S. UÉNo); $8 \hat{\jmath} \delta, 5$ 우우 (Ámadomari, 6-VI-1953, by S. UÊno); 2 令, 2 우 (Amadomari, 9-VI-1953, by S. UÉno) .

Type-localities: Yoriki and Amadomari, on the island of Nakanoshima, one of the Tokaras.

This remarkable new species inhabits the coral reef on the western coast of Nakanoshima. Its habitat is so far below the high-water mark that the species is submerged in water for long hours a day. At maximum low tide, it is found under stones of fragments of coral, coexisting with several species of Staphylinids (all new to science), Petrolisthes spp., Poly. cheira rufescens (BRANDT), Ophiocoma scolopendrina (LAMARCK), and other invertebrate animals.

Several individuals of callows and two individuals of different stages of larvae were also obtained in the same habitat. These discoveries suggest that pupation of this species takes place late in spring or early in summer. The larva seems to resemble that of $A$. yokohamae, but, as material for comparison is lacking, here is given only an illustration of a specimen in a mature stage, reserving the description.

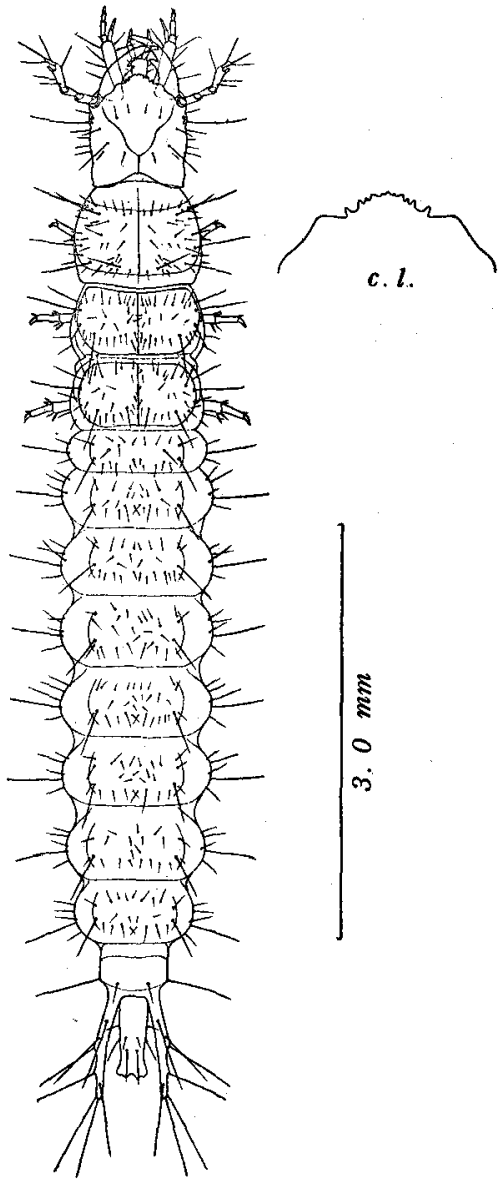

Fig. 4. Larva of Armatocillenus tsutsuii; c.l. : clypeal lobe.

\section{Peryphus (s. str.) semiluitus (H. W. BAtes)}

Bembidium (Peryphus) semiluitum H. W. BATEs, 1883, Trans. Ent. Soc. London, 275 ; typelocality : Honjo.

Bembidion (Peryphus) semiluitum, NetolitzKy, 1942, Koleopt. Rdsch., 28: 46; 1943, loc. cit., $29: 36$

$P$. semiluitus has long been neglected though it is distributed over the Pacific coast of southern Japan. The late Dr. NETouitzky may be a sole entomologist who has given an account of this interesting species. His brief notes, however, seem to become insufficient to recognize the species, since a new subspecies has been discovered 
by the present writer. It appears to be best to give its detailed redescription in. this occasion.

Length : $4.5-5.0 \mathrm{~mm}$ (from front margin of clypeus to anal end).

Winged. Shiny brownish black with strong aeneous tinge, ventral surface brown to dark brown; elytra dark brown, with olivaceous tinge, and with the apical area widely dark yellowish brown though this light area does not form defined spot and sometimes vanished according to individuals; labrum and mandibles brown; antepenultimate segment of maxillary palpi, antennal segments 1-3 with basal half of segment 4 , and legs flavous.

Head with fairly deep frontal furrows and moderately prominent supraorbital carinae; eyes prominent; genae very short; surface smooth, but several minute punctures present on the hind ends of frontal furrows; microsculpture absent on median areas but visible as reticulation in frontal furrows and on neck; antennae long, reaching basal one-third of elytra.

Pronotum subquadrate, convex, about 1.3 times wider than head, wider than long in a same proportion (a little wider in $q$ than in $\hat{o}$ ), widest at about five-eighths from base which is obviously wider than apex and slightly arcuate, apex about seven-ninths as wide as base, slightly but widely emarginate; sides gently rounded in front and slightly sinuate behind, side-gutter distinct throughout along side-border; hind angles nearly rectangular, each with an obtuse carina, front angles narrowly rounded; median line evident, transverse impressions shallow, basal foveae large and deep; basal area finely and sparsely punctate; microsculpture consisted of transverse lines at the sides but completely vanished on disk.

Elytra oblong ovate, convex, about 1.4 times wider than pronotum, about 1.6 times longer than wide; sides oblique at shoulders and very slightly emarginate before apices; punctate-striate, striae shallow, becoming shallower towards the sides, stria 7 nearly obsolete though marked with a row of fine punctures, stria 1 entire, others disappearing behind, stria 8 deep throughout, apical striole rudimentary; intervals flat; interval 3 with two dorsal pores adjoining stria 3 , placed at about two-sevenths and five-eighths from base respectively; humeral group of umbilicate pores four, ranged irregularly, fourth pore isolated; microsculpture formed by transverse lines.

Male genital organ well chitinized. Aedeagus rather elongate and arcuate, with right basal lobe produced; apex moderately bending to ventral side and narrowly rounded at the tip; a band of pubescence present at the proximal end of apical orifice. Copulatory pieces separated into four components: a dorsal whip-shaped piece which is suddenly twisted at the middle of inner sac from basal right to apical left, a bundle of fibres, placed at the right side of the basal part of dorsal whip, a reniform plate at the right basal side of the bundle of fibres, and an additional piece. Styles subequal in length, each provided with four apical setae.

Range: Honshu, Shikoku and Kyushu. Usually found under stones or refuses on the beaches of brackish water areas. 
The writer has examined the specimens from the following localities:

Honshu: the Tonegawa River, by Toride, Ibaraki Pref.; the Edogawa River, by Gyôtoku, Chiba Pref.; the Arakawa River, by Horikiri, Tokyo; the Kanogawa River, Shizuoka Pref.; the Shin-Yodogawa River, by Jûsô, Osaka; Hamadera, Osaka Pref.

Shikoku: Kyûkô, Kôchi.

Kyushu: Saéki, Ôita Pref.; Nobéoka, Miyazaki Pref.

The male genital organ was examined in the specimens from Gyôtoku, the ShinYodogawa, Kyûkô and Saéki.

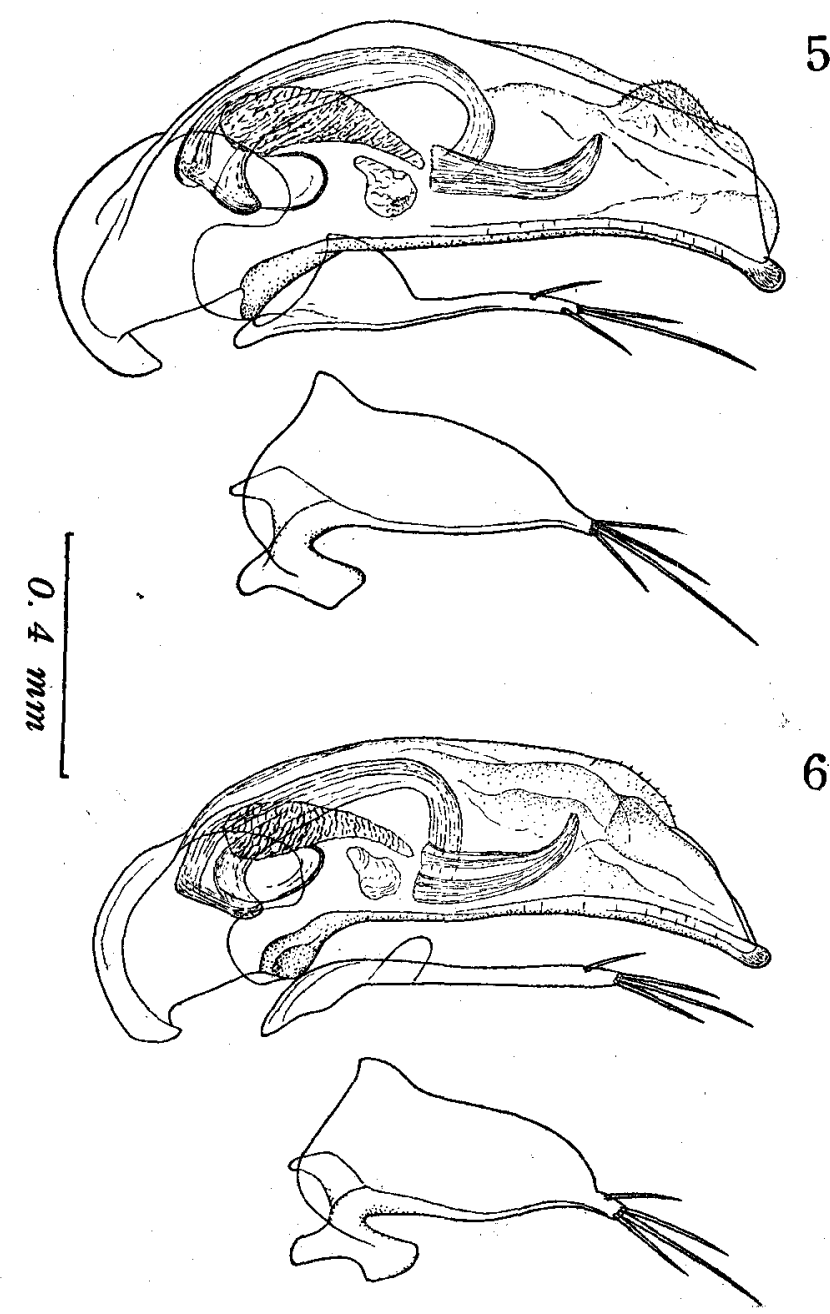

Figs. 5-6. Male genital organ, left lateral view, with left style removed.- 5. Peryphus semiluitus H. W. BATEs, of the Shin-Yodogawa River.-6. P. semiluitus nakanoshimensis S. UÉnO, subsp. nov., holotype. 
Peryphus (s. str.) semiluitus nakanoshimensis S. UÉNO, subsp. nov.

This new subspecies may be distinguished from the original form by the following features:

Length: $4.5 \mathrm{~mm}$ (from front margin of clypeus to anal end).

Colour as in the dark individuals of the original form, with antennal segments 4-11 rather lighter; the light area on the apical part of elytra very small.

Head and pronotum less transverse and the sides of elytra less rounded especially before apex, appearing a slenderer body-form as a whole. Elytral striae obviously deeper with much coarser punctures; intervals a little more convex especially on disk.

Aedeagus shorter, with apical part gradually tapering towards apex which is more narrowly rounded and is less bending ventrally; pubescent area at the proximal end of apical orifice smaller and the pubscence itself sparser.

Holotype: ô (Amadomari, 8-VI-1953, collected by, S. UÉNo); allotype: ㅇ (Satomura, 25-V-1953, by S. UÉNo).

Type-localities: Amadomari and Satomura, on the island of Nakanoshima, one of the Tokaras.

The type-specimens were obtained under stones on the intertidal zone, where small brooks flowed into the sea.

Asaphidion (s. str.) tenryuense kônoi S. UÉno, subsp. nov.

The present new subspecies may be discriminated from the original form by the following characteristics:

Length: $4.2 \mathrm{~mm}$ (from front margin of clypeus to anal end).

Pronotum a little more elongate, less narrower than head comparing with the original form, widest more in front and more suddenly contracted before the widest part; base much more strongly produced backwards, so that it is quite oblique on each side, forming an obtuse but distinct angle at middle.

Elytra shorter, a little wider in $q$ than in $\hat{\delta}, 1.65$ times longer than wide (1.75 times longer than wide in the original form); striae nearly obsolete, only the trace of striae 1 and 2 perceptible on basal three-fifths, while in the original form, striae 1-5 or even 6 present at least on basal half.

Male genital organ of quite the same structure with that of the original. Aedeagus elongate, with apical part slightly bending ventrally; basal orifice large and opened to right face, with right basal lobe produced; ventral side very slightly convex at the middle; apex produced and widely rounded. Copulatory pieces complex, separated into the following components: a well chitinized large piece at the left lateral side, a small twisted piece and a bundle of fibres at the right of the large piece and a right dorsal piece. Styles subequal in length, each furnished with three setae at apex.

Holotype: ô (Takao, 8-VI-1953, collected by H. KôNo); allotype: † (Satomura, 12-VI-1953, by S. UÉNO). 
Type-localities: Takao and Satomura, on the island of Nakanoshima, one of the Tokara Islands.

Asaphidion tenryuense (originally misread as A. tenryuensis)* was described based on a large female specimen collected at the Tenryûgawa River by Iijima-mura, Nagano Prefecture. The writer was able to examine this holotype-specimen through the courtesy of Mr. A. HaBU. Though two male specimens collected by Mr. K. Kurosa

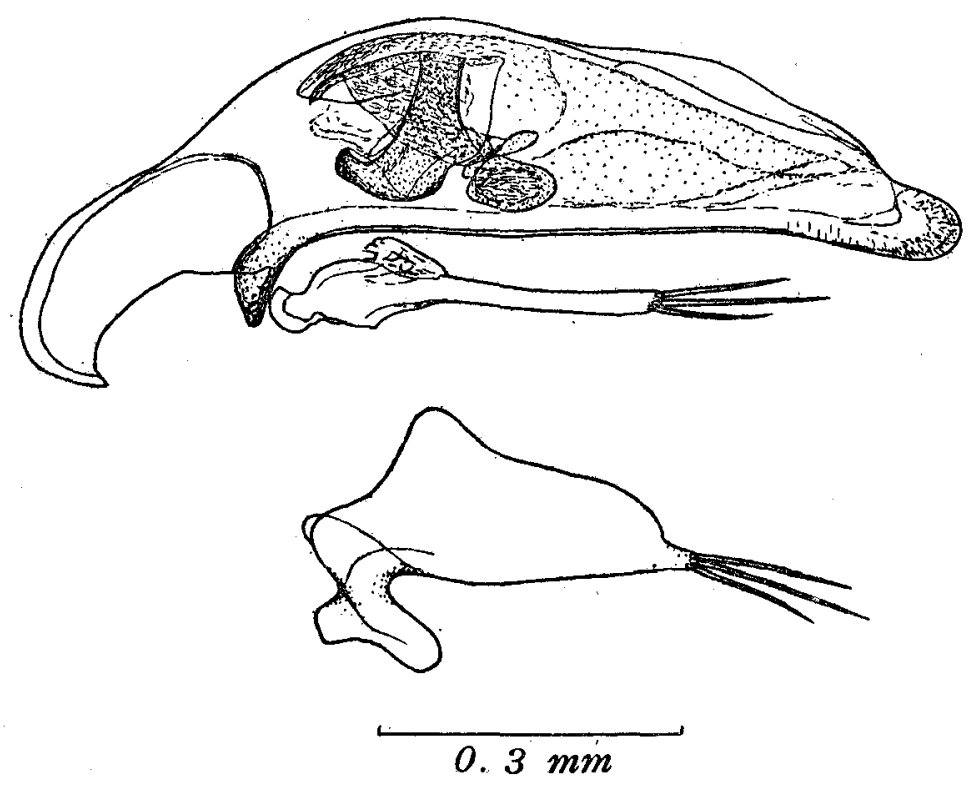

Fig. 7. Male genital organ of Asaphidion tenryuense kônoi S. UÉNo, subsp. nov., holotype; left lateral view, with left style removed.

at Sakasegawa, north-west of Osaka, on May 17th and 18th, 1940, are evidently smaller than the holotype, it seems that KUROSA's specimens are conspecific with $A$. tenryuense. The male genital organ of $A$ tenryuense tenryuense s. str., compared in this paper with the present new subspecies, was examined in one of these specimens from Sakasegawa.

Both the type-specimens of $A$. tenryuense kônoi were obtained under barks in the forest, coexisting with Peryphus morawitzi (CsIkI).

* Asaphidion tenryuensis HABU, 1954, Bull. Nation. Inst. Agric. Sci., Tokyo, (C), 4 : 288, fig. 6. 


\section{REFERENCES}

Andrewes, H. E. 1925. Notes on Oriental Carabidae-VII. Entomol. Monthly Mag., 61: 49-58. 1935. The Fauna of British India, including Ceylon and Burma. Coleoptera. Carabidae.

II. Harpalinae-I. London.

1938. On Cillenus Samouelle (Coleoptera, CARABIDAE). Proc. R. Ent. Soc. London, (B), $7: 190-196$.

BAtes, H. W. 1873 a. On the Geodephagous Coleoptera of Japan. Trans. Ent. Soc. London, 219-322.

1873 b. Descriptions of new genera and species of Geodephagous Coleoptera, from

China. Ibidem, 323-334.

1883. Supplement to the Geodephagous Coleoptera of Japan, chiefly from the collection of Mr. George Lewis made during his second visit, from February, 1880, to September, 1881. Ibidem, 205-290.

CsIKI, E. 1928. Carabidae: Mormolycinae, Harpalinae I, II. JUnk \& Schenkling, Coleopterorum Catalogus, Berlin, 97, 98.

DARlington, JR., P. J. 1953. A new Bembidion (Carabidae) of zoogeographic Interest from the Southwest Pacific. Coleopt. Bull., 7 (2): 12-16.

Dupuis, P. 1912. H. Sauter's Formosa-Ausbeute. Carabidae. (2me Contribution). Ann. Soc. ent. Belg., 56 : 308-338.

GanglBauer, L. 1892. Die Käfer von Mitteleuropa. Die Käfer der österreichisch-ungarischen Monarchie, Deutschlands, der Schweiz, sowie des französischen und italienischen Alpengebietes. I. Familienreihe Caraboidea. Wien.

HaBu, A. 1954. Descriptions of some new Carabid-beetles (Coleoptera) from Japan. Bull. Nation. Inst. Agric. Sci., Tokyo, (C), $4: 281-294$.

Jeannel, R. 1922. Les Trechinae de France. Ann. Soc. ent. France, 90 (for 1921) 161-192, 295345.

1928. Monographie des Trechinae. Morphologie comparée et distribution géographique d'un groupe de Coléoptères. (Troisième Livraison). L'Abeille, Paris, 35: 1-808.

1941. Coléoptères Carabiques. Première partie. Faune de France, Paris, 39.

MINOWA, S. 1932. New and hitherto-unrecorded Carabidae from Formosa (I). Trans. Nat. Hist. Soc. Formosa, 22 : 281-292.

Netolitzky, F. 1942. Bestimmungs-Tabellen europäischer Käfer. (9. Stück.). II. Fam. Carabidae. Subfam. Bembidiinae. 66. Gattung: Bembidion Latr. Bestimmungstabelle der Bembidion-Arten des paläarktischen Gebietes. (Mit Hinweisen auf holarktische, äthiopische und orientalische Arten.). Koleopt. Rdsch., Wien, 28: 29-68.

1943. Ditto. Ibidem, $28: 69-124 ; 29: 1-70$.

UÉno, S. 1953 a. The Coleoptera of Japan. (12). Shin Konchâ, Tokyo, 6 (11): 38-45. (In Japanese).

1953 b. The Coleoptera of Japan. (13). Ibidem, 6 (12): 37-43. (In Japanese). 